\title{
The Bacterial Flora of the Normal Gingival Sulcus*
}

\author{
BY MARY C. CROWLEY, W. A. BEPPLER aNd S. P. RAMFJORD**
}

$\mathrm{S}^{\mathrm{n}}$ INCE Waerhaug and Steen ${ }^{1}$ reported that the normal gingival sulcus of man and dog is sterile if free of calculu or other mechanical obstacles, several other investigators, ${ }^{2-5}$ have reported bacterial growth in samples from normal gingival sulci. However, these investigators all have used techniques that differed somewhat from the one used by Waerhaug and Steen.

Lack of bacterial growth may have been due to:

1. Sterilization of the sulcus by the germicide which was used for sterilization of the surfaces of the tooth and the gingiva at the time of the sampling.

2. Inadequate sample for growth of bacteria; may have been due also to the sampling instrument contacting remains of the surface disinfectant.

3. Inadequate and restrictive culturing techniques.

There are also numerous possibilities for a "false positive" sample from a gingival sulcus; the most important are contamination with organisms from saliva and lack of sterile bacteriologic technique.

The present study represents an attempt to clarify some of the controversial features of previous studies and to investigate, in a preliminary way, if the bacteria in the normal gingival sulcus are of the same genu as bacteria from periodontal pockets.

\section{METHOD}

Waerhaug and Steen's ${ }^{1}$ investigations were repeated with some modifications, and confined to humans since the significance

*This study was supported by U.S.P.H.S., Sponsored Research No. 04862.

* * School of Dentistry, The University of Michi gan, Ann Arbor, Michigan. of bacteriologic studies on animals of ten is highly uncertain when related to human conditions.

Samples were obtained from 10 individuals with clinically normal gingiva according to accepted criteria of normal color, form, density, level of attachment, depth of sulcus and lack of bleeding tendency.

The tooth and surrounding mucosa to be tested were isolated from the saliva of the oral cavity by cotton rolls and swabbed with iodine-glycerol (equal parts of $5 \%$ tincture of iodine and glycerol). Three minutes were allowed for germicidal action before sampling. An attempt was made to dry off the iodine-glycerol with blasts of air from a sterile hand-chip syringe the last minute before the sampling.

The sample was obtained by insertion of a sterile barbed broach* to the bottom of the sulcus and then removing it (instead of the smooth steel blade used by Waerhaug and Steen). The broach was aseptically removed from the broach holder and dropped into a tube of brain heart infusion medium (Difco) to which $0.25 \%$ agar had been added. Two samples with two different broaches were obtained from each individual area. One broach was dropped to the bottom of the tube to encourage growth of anaerobic species, while the other broach was deposited on a slanted surface of the medium and incubated in this position to allow opportunity for growth of aerobic organisms. Samples also were obtained by the same technique from 10 untreated periodontal pockets in 9 patients (see Table 1).

Control samples were obtained from the outer gingival surface adjacent to the sampling site. Two methods were used for this purpose. Either the gingival surface near the sulcus to be sampled was rubbed

*S. S. White Pulp Canal Cleaner, \#2 fine.

Page 52/502 
TABLE 1

Cultures from Normal Gingival Sulcus and Periodontal Pocket*

\begin{tabular}{lcc}
\hline & $\begin{array}{c}\text { Normal } \\
\text { Gingiva }\end{array}$ & $\begin{array}{c}\text { Periodontal } \\
\text { Pocket }\end{array}$ \\
\hline Number of areas cultured & 10 & 10 \\
Number of positive cultures & 9 & 10 \\
Number of surface cultures & 8 & 10 \\
Number of deep cultures & 9 & 10 \\
\hline
\end{tabular}

*Waerhaug and Steen's Methods, slightly modified

with a sterile cotton swab or scraped vigorously with a sterile platinum spatula. The swab was broken off below the area handled by the operator and immersed in 1-2 ml. of seed broth (heart infusion broth, (Difco), $+10 \%$ ascitic fluid, (Difco). The scrapings of the mucosa obtained by the platinum spatula also was deposited in similar seed broth.

Brain heart infusion $+0.25 \%$ agar and blood agar plates (blood agar base, (Difco) plus $5 \%$ defibrinated rabbit blood) were inoculated from the seed broth and incubated aerobically and anaerobically.

\section{RESULTS}

No bacterial organisms were cultivated from the samples obtained from the control areas of the outer gingival surface. This showed that the iodine-glycerol had prevented bacterial growth from these sample areas.

The broach samples from within the normal gingival sulcus, however, resulted in bacterial growth in 9 out of 10 cases (see Table 1). Only in one instance was the sample from the sulcus sterile. Growth resulted from all of the samples from the 10 periodontal pockets.

A more detailed bacteriologic examination of the cultures from some of the samples, both aerobically and anaerobically by cultivation of transfer cultures in a Brewer anaerobic jar showed the same genus of or-

TABLE 2

Qualitative Findings from BHI Cultures

\begin{tabular}{|c|c|c|c|c|c|c|c|c|c|c|c|c|}
\hline & \multicolumn{3}{|c|}{$\begin{array}{l}\text { Normal } \\
\text { Gingiva }\end{array}$} & \multicolumn{9}{|c|}{$\begin{array}{c}\text { Periodontal } \\
\text { Pockets }\end{array}$} \\
\hline Organisms & 2 & 8 & 10 & 3 & 5 & 7 & 9 & 9.1 & 11 & 11.1 & 13 & 17 \\
\hline Streptococcus & + & + & + & + & + & + & + & + & + & 0 & + & + \\
\hline $\begin{array}{l}\text { Other Gram } \\
\text { positive organisms }\end{array}$ & + & + & + & + & + & + & + & + & 0 & + & 0 & + \\
\hline Gram-negative cocci & 0 & 0 & 0 & 0 & 0 & 0 & 0 & 0 & 0 & 0 & 0 & 0 \\
\hline Actinomyces & + & 0 & + & 0 & 0 & 0 & 0 & 0 & 0 & + & + & 0 \\
\hline Coryne-bacterium & + & + & 0 & + & 0 & + & 0 & 0 & 0 & + & 0 & 0 \\
\hline Lactobacillus & 0 & 0 & 0 & 0 & 0 & 0 & 0 & 0 & 0 & 0 & + & 0 \\
\hline Other Gram-positive rods & + & 0 & + & 0 & + & + & + & + & + & 0 & + & + \\
\hline Fuso-bacterium & 0 & 0 & + & 0 & 0 & 0 & 0 & 0 & 0 & 0 & 0 & 0 \\
\hline Gram-negative rods & 0 & 0 & + & 0 & 0 & 0 & + & 0 & 0 & 0 & 0 & + \\
\hline Gram-negative filaments & 0 & + & 0 & 0 & 0 & 0 & 0 & 0 & 0 & 0 & 0 & 0 \\
\hline Total number of isolates & 9 & 5 & 7 & 8 & 6 & 16 & 6 & 4 & 4 & 5 & 11 & 8 \\
\hline
\end{tabular}


ganisms from the normal gingival sulci as from the periodontal pockets (see Table 2 ).

Species identification of the organisms was not attempted, since the iodine glycerol obviously had influenced the samples; and the nutritional limitations imposed by the isolation medium had further restricted the bacterial growth so that it would not be representative of the bacterial flora in the gingival sulcus or the periodontal pockets.

The results from this study confirm the observations of previous investigators who found that the gingival sulcus can harbor a variety of bacterial forms in the absence of clinically demonstrable calculus or periodontal disease.

\section{CONCLUSIONS}

1. The normal gingival sulcus contains a variety of microorganisms.

2. The same genus of bacteria were found in samples from normal gingival sulci and periodontal pockets in this limited study.

3. Iodine-glycerol prevented bacterial grow th completely in samples from the gingival surface, and interfered with bacterial grow th in samples from the gingival sulcus.

\section{BIBLIOGRAPHY}

1. Waerhaug, Jens, and Steen, Emil: The presence or absence of bacteria in gingival pockets and the reaction in healthy pockets to certain pure cultures. Odontologisk Tidskrift, 60:1-24, 1952.

2. Boyd, W. S., and Rosenthal, S. L.: The presence of bacteria in the healthy gingival sulcus. J. Dent. Res., 37:288-291, 1958 .

3. Bervell, S. F. A.: En ny teknikk ved bakteriologisk undersökelser av fysiologiske tannkjöttslommer. Norsk Tandl. Tid. 70:425-433, 1960.

4. Gavin, J. B., and Collins, A. A.: The occurrence of bacteria within the clinically healthy gingival crevice. J. Periodont., 32:198-202, 1961.

5. Egelberg, J., and Cowley, G.: The bacterial state of different regions within the clinically healthy gingival crevice. Acta Odont. Scand. 21:289-296, 1963.

\section{FIRST DISTRICT DENTAL SOCIETY}

The First District Continuing Education Program presents the following courses during December 1964 and January 1965:

The Indications for and the Construction of Interceptive Orthodontic Appliances, Leonard J. Seide. Dec. 3, 4 (9:30 a.m. to 4:00 p.m.-Tuition $\$ 90.00)$.

Practical Periodontal Therapy for the General Practitioner, Henry I. Greene. Dec. 15, 16 (9:30 a.m. to 4:00 p.m.-Tuition $\$ 90.00)$.

The Handicapped Patient, Jerry J. Adelson. Jan. 8, 9 (9:30 a.m. to 4:00 p.m. and 9:30 a.m. to 12:00 Noon-Tuition $\$ 90.00$ ).

Practical Techniques of Analgesia, Warren H. Hecht. Jan. 13, 14, 15 (9:00 a.m. to 4:00 p.m.Tuition \$115.00).

A Comprehensive Survey of Some of the Most Recent Developments in Restorative Dentistry, A. Milton Bell. Jan. 25, 26, 27 (9:30 a.m. to 4:00 p.m.-Tuition \$130.00).

All members of the American Dental Association are eligible for registration in these courses.

A registration fee of $\$ 5.00$ is required once for the term from each applicant who is not a member in good standing of the FIRST DISTRICT DENTAL SOCIETY.

In applying for admission to the foregoing courses, please enclose separate registration fee check with first tuition check. Make all checks payable to First District Continuing Education Program, and mail to the First District Dental Society, Statler Hilton, New York City 10001.

For further information on these courses, write to Jerry J. Adelson, Supervisor, Continuing Education Program, First District Dental Society, Statler Hilton Hotel, 7 th Avenue and West 33 rd Street, New York, New York 10001. 